\title{
Environmental Hazards Resulting from the Use of Public Roads in Krakow, Poland
}

\author{
Dorota Pierri* \\ AGH University of Science and Technology, Department of Hydrogeology and Engineering Geology, \\ Faculty of Geology, Geophysics and Environmental Protection, Krakow, Poland
}

Received: 26 July 2019

Accepted: 18 September 2019

\begin{abstract}
The use of communication routes is associated with general awareness of the high environmental pollution caused by heavy metals. Research carried out on the example of the busy Opolska Street in Krakow, Poland, showed that the surrounding land is clean and does not show any signs of pollution. The geometric mean contents of metals and metalloids in the ground are as follows: for arsenic $\mathrm{As}^{3+}-0.0088 \mathrm{mg} / \mathrm{kg}$, cadmium $\mathrm{Cd}^{2+}-0.0005 \mathrm{mg} / \mathrm{kg}$, copper $\mathrm{Cu}_{2}^{+}-0.0406 \mathrm{mg} / \mathrm{kg}$, mercury $\mathrm{Hg}^{2+}-0.0001 \mathrm{mg} / \mathrm{kg}$, nickel $\mathrm{Ni}^{2+}-0.0077 \mathrm{mg} / \mathrm{kg}$, lead $\mathrm{Pb}^{2+}-0.0028 \mathrm{mg} / \mathrm{kg}$ and zinc $\mathrm{Zn}^{2+}-0.0160 \mathrm{mg} / \mathrm{kg}$. The main threat to the ground and water environment was the maintenance of the road during the winter period. On a $58-\mathrm{m}$ research section, after the measurement period, the amount of chlorides increased in the soil environment by over $1 / 2 \mathrm{~kg}$, i.e., $+561 \mathrm{mg} / \mathrm{kg}$ ( +592 for December and $+530 \mathrm{mg} / \mathrm{kg}$ for January). A green belt separating roadways is a permanent element of the exposed ground. The total length of Opolska Street is 3,400 $\mathrm{m}$ and the green belt is about $2,900 \mathrm{~m}$, with an average width of $4 \mathrm{~m}$ along the entire length of the street. Through this section of land alone, more than $2 \frac{1}{2}$ tons of chlorides enter the ground and then into the shallow Quaternary groundwater. This value translates into 4 tons of road salt ( $\mathrm{NaCl}$ rock salt).
\end{abstract}

Keywords: road salting, groundwater pollution, soil pollution, human pressure, Krakow

\section{Introduction}

The biggest sources of large-scale pollution of soil and water environment in the world are agriculture and air pollution. In urban areas and large cities, where areas are built-up, it is difficult to assess the direct impact of these factors on the quality of soils and groundwater. The possibility of substances entering the environment depends primarily on the geological

*e-mail: pierri@agh.edu.pl structure and hydrogeological conditions; however, the main direct factors affecting water pollution in Krakow city are anthropogenic stratifications [1]. These are mainly former post-industrial pollution sources on the surface (heaps, dumps) but also the maintenance of public roads.

Maintaining the road target standard, in particular, removing snow and winter slipperiness (slush) is an important aspect of any governmental budget. Annually, Polish cities allocate from a few to a dozen million zlotys for this purpose. Preparing for winter is a large logistical project, in particular the purchase and storage of road salt or the servicing of 
the heavy road equipment. According to the General Directorate for National Roads and Highways [24], over 500,000 tons of road salt is used in Poland throughout the year. This is a large amount in comparison to Scandinavian countries. In Sweden, despite the occurrence of a humid continental and subpolar climate, the annual use of salt in road engineering varies from 200,000 to 300,000 tons [5]. Attempts to reduce the use of road salt in Poland, however, are ineffective due to legal conditions and/or for economic reasons.

Regulations of the Minister of the Environment on types of products that can be used on roads (Journal of Laws No. 230, item 1960) lists two types: non-chemical and chemical agents [6]. The roughening material may be sand or a natural aggregate. The roughness of the substrate along with the removal of winter slipperiness is obtained in turn by sprinkling roads with sand mixed with $10-50 \%$ salt. However, the use of chemicals is much more effective; they are used to remove black ice and icing, as well as to prevent the formation of ice and slippery slush.

The cheapest chemical agent is sodium chloride $(\mathrm{NaCl})$, and its effectiveness in stimulating the decomposition of black ice is obtained after a time of 1 5 to 30 minutes at 10 to $20 \mathrm{~g} / \mathrm{m}^{2}$ [5]. The most common mixture used on Polish roads is composed of $97 \%$ $\mathrm{NaCl}+2.5 \% \mathrm{CaCl}_{2}+0.5 \% \mathrm{~K}_{4}\left[\mathrm{FeCN}_{6}\right]$. The most effective composition is (a) 60 to $80 \%$ of grains with a diameter of 3 to $6 \mathrm{~mm}$, (b) a maximum of $5 \%$ of grains with a diameter of $6 \mathrm{~mm}$ and (c) $5 \%$ of grains with a diameter of less than $0.18 \mathrm{~mm}[5,7,8]$. The effectiveness of road salt increases when mixing sodium chloride $(\mathrm{NaCl})$ with magnesium chloride $\left(\mathrm{MgCl}_{2}\right)$ at a ratio of 4:1. Currently, due to economic reasons, there are no alternative chemicals in Poland for common road salt.

The general conditions for the use of chemical agents, specified in the regulations [6], assume that the spreading should take place in the roadway or on the pavement. Therefore, it is forbidden to apply road salt in green zones - both in the green belt and outside the pavement. The use of road salt is a serious threat to the quality of soils and groundwater [9-12]. Thus, some cities in Poland, fearing for the state of the environment, impose financial penalties for the use of salt on the sidewalks. Such a penalty can be obtained, among other cities, in Zabrze. These actions are fully justified, especially considering that a machine spreading road salt has little control over the spread range. The average loading of the sand spreader is 5 tons of material (sand or chemical mix), and the salting density is 1 kilogram of salt per $1 \mathrm{~m}^{2}$ [13]. The availability of salt deposits in the south of Poland and the density of the public road network in Krakow (i.e., $3.86 \mathrm{~km} / \mathrm{km}^{2}$ ) is large [14, 15]. Therefore, research has been carried out on the impact of the use of chemicals in winter on the quality of ground in Krakow, and ultimately on the quality of shallow groundwater. In addition, the quality of the soil for content of heavy metals was examined.

\section{Outline of Hydrogeological Conditions}

The city of Krakow is located in an area with a complex geological structure that results from its location on the border of three major tectonic units. These are the Silesian-Krakow Monocline, the Miechow Fault Basin, and the Carpathian Tectonic Depression. A characteristic feature of the local structure is the presence of numerous but small rift valleys and horsts. The complex geological structure of Krakow implies the complexity of the region's hydrogeological conditions. The rift valleys are filled with permeable Cretaceous and Jurassic deposits. Impermeable Tertiary argil fills the tectonic horsts. The main base of groundwater drainage is the Vistula River. Its valley is filled with Quaternary deposits or limited by Jurassic rocks. It should be noted, however, that the groundwater flow in Krakow is not so simple. In the discussed area, there are numerous hydro-structures separated by faults, between which the flow is extremely difficult.

Three aquifers occur in Krakow: Quaternary, Tertiary, and Jurassic [1, 16]. The Quaternary aquifer is associated with the occurrence of sands and gravels with silts, clays, and argil interbeds, and locally, peats in sediments that fill the Vistula Valley. The thickness of these layers reaches $30 \mathrm{~m}$ in the valley, while the youngest deposits are anthropogenic [1]. The Quaternary aquifer in the research area is unconfined, with a water table at a depth of about 2 to 3 meters. Recharge takes place through the direct infiltration of atmospheric precipitation. The direct drainage base is Sudół Stream (the left tributary of the Białucha River) at a distance of 38.0 to approx. $100 \mathrm{~m}$ at the furthest point from the research area. The stream provides polluted waters with traces of household wastewater inflow [17]. The stream bed is scarped about 2 to 3 meters below the ground surface. Sudól at the research area is $2 \mathrm{~m}$ wide.

The elevation of the surface of the studied area ranges between 216 and $217 \mathrm{~m}$ above sea level. According to the Soil map of Krakow [18], the research area includes the zone between built-up areas (i.e., urban and garden soils). This means that anthropogenic soils dominate in the area and constitute a mixture of native soil, i.e., Quaternary sediments (sand, gravel) as well as bricks and debris. The size of grains of construction origin is up to $30 \mathrm{~mm}$. The presence of large grains of porous material affects the high values of soil filtration parameters, including the effective infiltration rate and the humidity of anthropogenic soil. The studied soil, despite its local heterogeneity, is one continuous geotechnical layer.

\section{Material and Methods}

The study on the impact of maintaining the target standard of public roads in Krakow related to removing snow and slush was carried out at the turn of 2018 and 2019 in the area of Opolska Street in the Krowodrza 


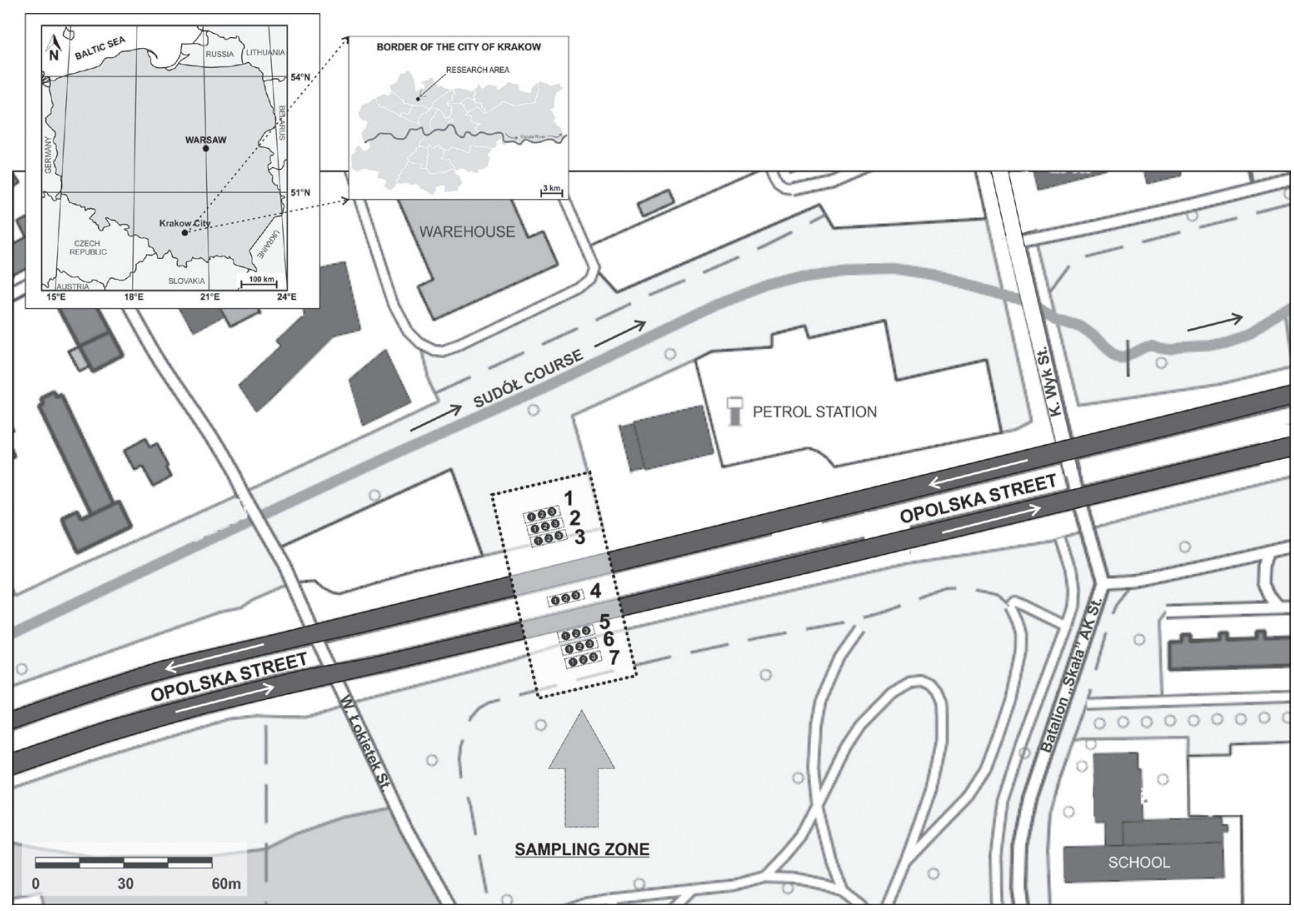

Fig. 1. Site plan with the location of geoengineering boreholes 1-7 (source of map: visualization BDOT10k [30]).

District. A fragment of the main public road in Krakow with high traffic numbers was selected for the study. It is an urban road with a green belt in the middle and adjoining green areas. It was possible to make geoengineering boreholes (Fig. 1) in close proximity to the road.

As part of the research, 7 such geoengineering boreholes (Nos. 1 to 7 ) were made on a $58-\mathrm{m}$ research section. Three series of measurements were carried out during field tests in:

- October (4/10/2018) to assess the initial state preceding the snow season.

- December (22/12/2018).

- January (17/01/2019), respectively after one week of continuous precipitation and the use of road salt in Krakow.

In fact, 21 geoengineering boreholes were made at 7 points in three measurement series. To simplify the analysis and interpretation, the numbering was narrowed down to the testing zones (Fig. 1).

Soil samples were taken from the surface and, using a drilling set with a tubular auger, from a depth of 0.25 , $0.50,0.75$ and $1.00 \mathrm{~m}$ respectively. Subsequently, soil samples were dried to a constant weight at $105 \pm 5^{\circ} \mathrm{C}$. The material was passed through a sieve with a mesh size of $4 \mathrm{~mm}$. A sample for the leaching test was maintained as a representative sample by quartering (PN-EN 12457 - 2:2002 and 2:2006). The eluates in a $1: 2$ ratio were filtered through a $0.45 \mu \mathrm{m}$ filter and then titrated to determine the concentration of chlorides Cl- (PN-ISO 9297:1994) (Table 2). Some of the eluates were subjected to chemical analysis in the accredited Hydrogeochemical Laboratory of AGH-UST. In the laboratory, a full range of inorganic substances was determined (Table 2), including $\mathrm{HCO}_{3-}$ (titration - PNISO 9297:1994), major elements (inductively coupled plasma optical emission spectrometry (ICP-OES) - PNEN ISO 11885:2009) and minor elements (inductively coupled plasma - mass spectrometry (ICP-MS) - PNEN ISO 17294-1:2007, PN-EN ISO 17294-2:2006).

During the research, meteorological parameters were monitored during the autumn and winter period, i.e., from October 2018 until the end of February 2019 (Fig. 2). The information was obtained from an official information service - the Weather Service of the Institute of Meteorology and Water Management National Research Institute.

\section{Results and Discussion}

\section{Soil Contamination with Heavy Metals and Metalloids}

Communication traffic is commonly associated with significant contamination of the adjacent soil with heavy metals. Mineralization and chemical composition of the ground (deposits in general) depends, therefore, not only on the natural, original composition of their formation but primarily on the number of physical and chemical processes occurring in the ground environment $[19,20]$.

Chemical analysis of eluates from the leaching tests showed that there are 3 dominant types: sodiumchloride $(\mathrm{Na}-\mathrm{Cl})$, sodium-bicarbonate $\left(\mathrm{Na}-\mathrm{HCO}_{3}\right)$, and calcium-bicarbonate $\left(\mathrm{Ca}-\mathrm{HCO}_{3}\right)$.

The investigation of the content of metals and metalloids in the soil showed low concentration values. The highest values were determined for aluminium 

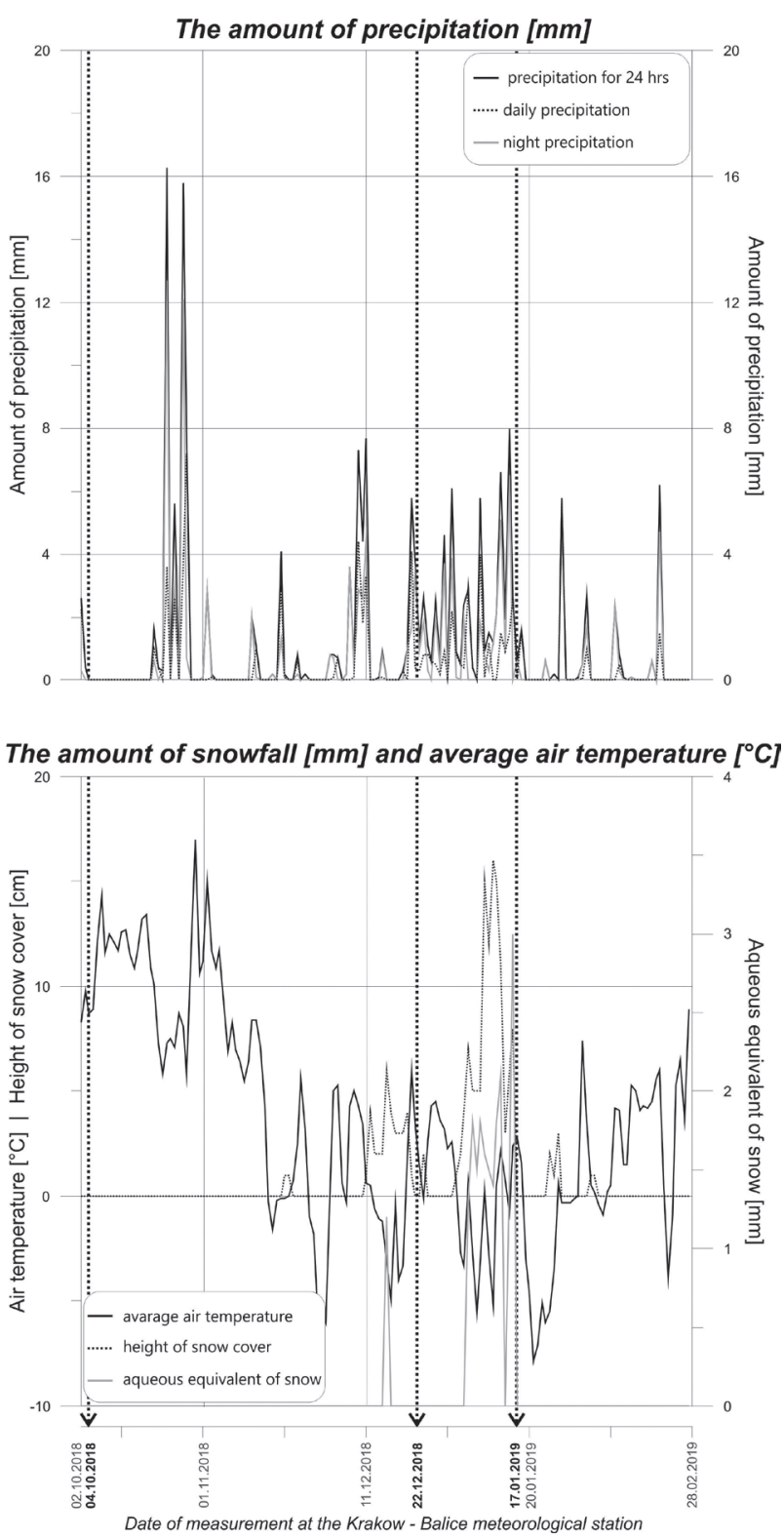

Fig. 2. Weather changes during the research period: October 2018-February 2019.

$\left(\mathrm{Al}^{3+} \max 2.94 \mathrm{mg} / \mathrm{kg}\right)$ and iron $\left(\mathrm{Fe}^{2+} \max 2.07 \mathrm{mg} / \mathrm{kg}\right)$ (Table 1). Both elements were determined in borehole No. 5 on the south side of Opolska Street (Table 1, Figs 3-5). The geometric mean contents of the most frequently analysed metals and metalloids [21] are as follows: for arsenic $\mathrm{As}^{3+}-0.0088 \mathrm{mg} / \mathrm{kg}$, cadmium $\mathrm{Cd}^{2+}-0.0005 \mathrm{mg} / \mathrm{kg}$, copper $\mathrm{Cu}^{2+}-0.0406 \mathrm{mg} / \mathrm{kg}$, mercury $\mathrm{Hg}^{2+}-0.0001 \mathrm{mg} / \mathrm{kg}$, nickel $\mathrm{Ni}^{2+}-0.0077 \mathrm{mg} / \mathrm{kg}$, lead $\mathrm{Pb}^{2+}-0.0028 \mathrm{mg} / \mathrm{kg}$, and zinc $\mathrm{Zn}^{2+}-0.0160 \mathrm{mg} / \mathrm{kg}$.

The general distribution of metal and metalloid contents in the ground confirms the highest concentrations in the axis of the road in the green belt (borehole No. 4), which then decrease with distance. The transfer of the maximum concentrations of several elements $\left(\mathrm{Cu}^{2+}, \mathrm{Pb}^{2+}, \mathrm{Al}^{3+}, \mathrm{Fe}^{2+}\right)$ toward the southerly direction (borehole No. 5) is probably caused by the slight gradient of the terrain.

\section{Soil Salinity}

Chlorides, as conservative substances, indicate the maximum extent of pollution spreading in the soil and water environment $[22,23]$. Therefore, they were treated as a marker of pollution caused by salting public roads (Table 2, Fig. 6). The results from October 2018 indicate the initial distribution of chlorides in the ground for the autumn period. The increase in the concentration of chlorides in the borehole drilled in the green belt separating the roadways is clearly marked (borehole No. 4). Maximum concentrations were determined on the surface $(208 \mathrm{mg} / \mathrm{kg})$ and at a depth of $0.50 \mathrm{~m}$ $(232 \mathrm{mg} / \mathrm{kg})$. The values in the road axis are about 5 times higher than in the adjoining areas, where the values range from 14 to $110 \mathrm{mg} / \mathrm{kg}$, with a geometric mean of $28 \mathrm{mg} / \mathrm{kg}$.

The study of soil quality in winter [24], each time after about 1 week of intense snowfall and the use of road salt to maintain the target standard, show comparable results (Fig. 6). In December 2018, chloride concentration in the road axis reached a maximum value of $472 \mathrm{mg} / \mathrm{kg}$, and at a depth of $0.75 \mathrm{~m}$ $206 \mathrm{mg} / \mathrm{kg}$, respectively.

A similar distribution is observed for the results of January 2019. The maximum value of chloride concentration on the surface in the road axis was $266 \mathrm{mg} / \mathrm{kg}$, and at a depth of 0.25 and $0.75 \mathrm{~m}-272$ and $230 \mathrm{mg} / \mathrm{kg}$ respectively. A high value was observed on the surface in boreholes No. 5 and 6, at the levels of $236 \mathrm{mg} / \mathrm{kg}$ and $214 \mathrm{mg} / \mathrm{kg}$ respectively.

An increased concentration of chlorides in the research section in the axis of the roadway at a depth of $0.50 \mathrm{~m}$ in October 2018, and later in December 2018 and January 2019 at a depth of $0.75 \mathrm{~m}$, may indicate infiltration of chlorides accumulating in the ground (borehole No. 4). It is the maximum concentration resulting from the dilution of chloride pollution while salting the public road in the winter 20172018. This infiltration takes place in accordance with the piston displacement model. An evaluation of the vertical filtration time at incomplete saturation, i.e., the vadose zone, was calculated according to the formula $[25,26]$ :

$$
t_{a}=\sum_{1}^{n} \frac{m_{a i} \times w_{0 i}}{J_{E}}
$$

$\mathbf{m}_{\mathbf{a}}-$ thickness of subsequent layers $[\mathrm{m}], \mathbf{t}_{\mathbf{a}}-$ vertical seeping time $[\mathrm{a}], \mathbf{w}_{\mathbf{0} \mathbf{i}}$ - average volume humidity of subsequent layers of the vadose zone [-], $\mathbf{J}_{\mathbf{E}}-$ effective annual infiltration $\left(\mathrm{J}_{\mathrm{E}}=\mathrm{P} \times \omega\right)[\mathrm{m} / \mathrm{a}], \mathbf{P}-$ annual precipitation [m/a], $\boldsymbol{\omega}$ - effective infiltration rate [-], $\mathbf{i}$ - number of the subsequent layer, $\mathbf{n}$ - amount of layers

Assuming one thick layer of anthropogenic deposits in the vadose zone of Opolska Street in Krakow, as well as assuming average values of the effective infiltration rate $\omega=0.20$, and the humidity of anthropogenic soil 
Table 1. Concentrations of selected minor elements $[\mathrm{mg} / \mathrm{kg}]$ in ground samples from boreholes 1-7.

\begin{tabular}{|c|c|c|c|c|c|c|c|c|}
\hline Borehole & No. 4 & No. 4 & No. 5 & No. 5 & No. 3 & No. 3 & No. 2 & No. 2 \\
\hline $\begin{array}{c}\text { Distance from } \\
\text { the road axis }[\mathrm{m}]\end{array}$ & 1.5 & 1.5 & 16.0 & 16.0 & 23.5 & 23.5 & 29.0 & 29.0 \\
\hline $\begin{array}{l}\text { Depth of sampling } \\
{[\mathrm{m} \mathrm{bgl}]^{*}}\end{array}$ & 0.25 & 1.00 & 0.25 & 1.00 & 0.25 & 1.00 & 0.25 & 1.00 \\
\hline $\mathrm{Ag}$ & 0.0225 & 0.0005 & 0.0111 & 0.0005 & 0.0245 & 0.0235 & 0.0089 & 0.0005 \\
\hline $\mathrm{Al}$ & 0.0239 & 2.9386 & 0.0144 & 0.8843 & 0.5770 & 0.6947 & 0.0763 & 0.0513 \\
\hline As & 0.0122 & 0.0232 & 0.0053 & 0.0304 & 0.0032 & 0.0022 & 0.0122 & 0.0095 \\
\hline B & 0.1596 & 0.1551 & 0.1066 & 0.5762 & 0.0322 & 0.0424 & 0.0830 & 0.0888 \\
\hline $\mathrm{Ba}$ & 0.1057 & 0.0870 & 0.0705 & 0.0383 & 0.0233 & 0.0278 & 0.0772 & 0.0429 \\
\hline $\mathrm{Be}$ & 0.0003 & 0.0003 & 0.0003 & 0.0003 & 0.0003 & 0.0003 & 0.0003 & 0.0003 \\
\hline $\mathrm{Bi}$ & 0.0016 & 0.0013 & 0.0021 & 0.0210 & 0.0011 & 0.0003 & 0.1073 & 0.0019 \\
\hline $\mathrm{Br}$ & 0.6489 & 0.3496 & 0.3295 & 0.9104 & 0.0500 & 0.0500 & 0.0500 & 0.0500 \\
\hline $\mathrm{Cd}$ & 0.0009 & 0.0008 & 0.0002 & 0.0016 & 0.0002 & 0.0002 & 0.0007 & 0.0013 \\
\hline $\mathrm{Co}$ & 0.0006 & 0.0017 & 0.0004 & 0.0052 & 0.0005 & 0.0001 & 0.0010 & 0.0010 \\
\hline $\mathrm{Cr}$ & 0.0025 & 0.0025 & 0.0025 & 0.0025 & 0.0025 & 0.0025 & 0.0025 & 0.0025 \\
\hline Cs & 0.0001 & 0.0001 & 0.0001 & 0.0001 & 0.0001 & 0.0001 & 0.0001 & 0.0001 \\
\hline $\mathrm{Cu}$ & 0.1066 & 0.0582 & 0.0361 & 0.1342 & 0.0170 & 0.0059 & 0.0591 & 0.0418 \\
\hline $\mathrm{Fe}$ & 0.0486 & 2.0739 & 0.0281 & 0.7570 & 0.4272 & 0.4690 & 0.1323 & 0.0510 \\
\hline $\mathrm{Ga}$ & 0.0029 & 0.0035 & 0.0022 & 0.0016 & 0.0009 & 0.0011 & 0.0026 & 0.0015 \\
\hline $\mathrm{Hg}$ & 0.0002 & 0.0002 & 0.0002 & 0.0001 & 0.0001 & 0.0001 & 0.0001 & 0.0001 \\
\hline I & 0.0050 & 0.0050 & 0.0050 & 0.0050 & 0.0050 & 0.0050 & 0.0050 & 0.0050 \\
\hline $\mathrm{Li}$ & 0.0098 & 0.0021 & 0.0036 & 0.0072 & 0.0029 & 0.0027 & 0.0005 & 0.0005 \\
\hline $\mathrm{Mn}$ & 0.1106 & 0.0986 & 0.0227 & 0.3338 & 0.0170 & 0.0248 & 0.1208 & 0.2165 \\
\hline Mo & 0.0090 & 0.0115 & 0.0034 & 0.0339 & 0.0013 & 0.0025 & 0.0202 & 0.0045 \\
\hline $\mathrm{Ni}$ & 0.0092 & 0.0160 & 0.0038 & 0.0257 & 0.0055 & 0.0033 & 0.0064 & 0.0073 \\
\hline $\mathrm{Pb}$ & 0.0015 & 0.0231 & 0.0007 & 0.0048 & 0.0057 & 0.0050 & 0.0013 & 0.0010 \\
\hline $\mathrm{Rb}$ & 0.0021 & 0.0030 & 0.0018 & 0.0037 & 0.0011 & 0.0012 & 0.0032 & 0.0034 \\
\hline $\mathrm{Sb}$ & 0.0200 & 0.0183 & 0.0058 & 0.0256 & 0.0014 & 0.0005 & 0.0072 & 0.0110 \\
\hline $\mathrm{Se}$ & 0.0050 & 0.0050 & 0.0050 & 0.0050 & 0.0050 & 0.0050 & 0.0050 & 0.0050 \\
\hline $\mathrm{Sn}$ & 0.0005 & 0.0005 & 0.0005 & 0.0005 & 0.0005 & 0.0005 & 0.0005 & 0.0025 \\
\hline $\mathrm{Sr}$ & 0.1000 & 0.1000 & 0.1000 & 0.1000 & 0.1000 & 0.1000 & 0.1000 & 0.1000 \\
\hline $\mathrm{Te}$ & 0.0050 & 0.0050 & 0.0050 & 0.0050 & 0.0050 & 0.0050 & 0.0050 & 0.0050 \\
\hline $\mathrm{Ti}$ & 0.0100 & 0.0100 & 0.0100 & 0.0100 & 0.0100 & 0.0100 & 0.0100 & 0.0100 \\
\hline $\mathrm{Tl}$ & 0.0001 & 0.0001 & 0.0001 & 0.0001 & 0.0001 & 0.0001 & 0.0003 & 0.0001 \\
\hline $\mathrm{U}$ & 0.0005 & 0.0037 & 0.0003 & 0.0035 & 0.0001 & 0.0001 & 0.0003 & 0.0001 \\
\hline $\mathrm{V}$ & 0.0039 & 0.0145 & 0.0005 & 0.0115 & 0.0005 & 0.0005 & 0.0059 & 0.0029 \\
\hline $\mathrm{W}$ & 0.0089 & 0.0072 & 0.0007 & 0.0271 & 0.0002 & 0.0002 & 0.0022 & 0.0021 \\
\hline $\mathrm{Y}$ & 0.0004 & 0.0188 & 0.0006 & 0.0033 & 0.0051 & 0.0072 & 0.0006 & 0.0003 \\
\hline $\mathrm{Zn}$ & 0.0239 & 0.0341 & 0.0050 & 0.1718 & 0.0050 & 0.0050 & 0.0050 & 0.0487 \\
\hline $\mathrm{Zr}$ & 0.0010 & 0.0080 & 0.0010 & 0.0076 & 0.0010 & 0.0010 & 0.0010 & 0.0010 \\
\hline
\end{tabular}




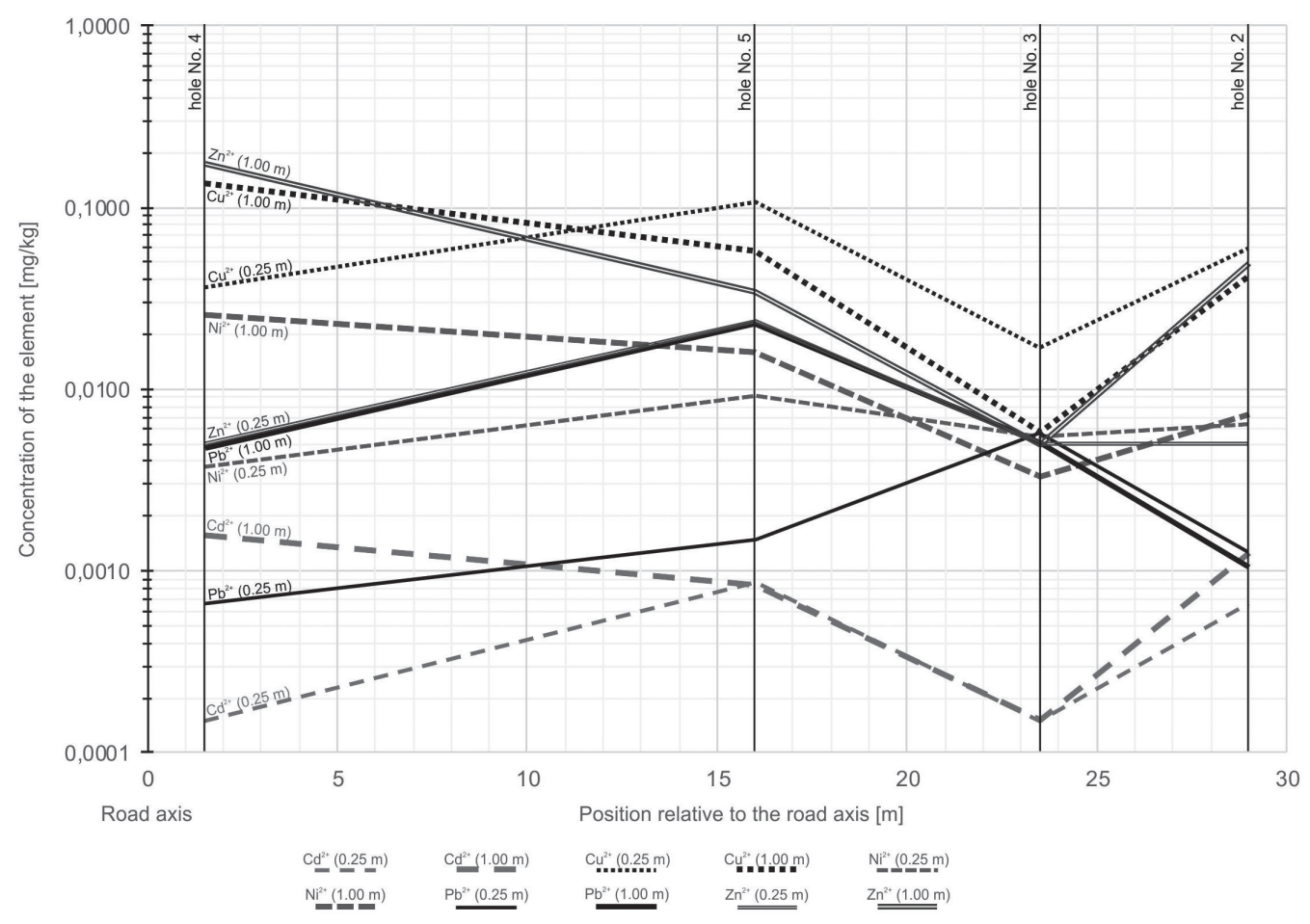

Fig. 3. Concentrations of selected metals $[\mathrm{mg} / \mathrm{kg}]$ in ground samples from boreholes 1-7.

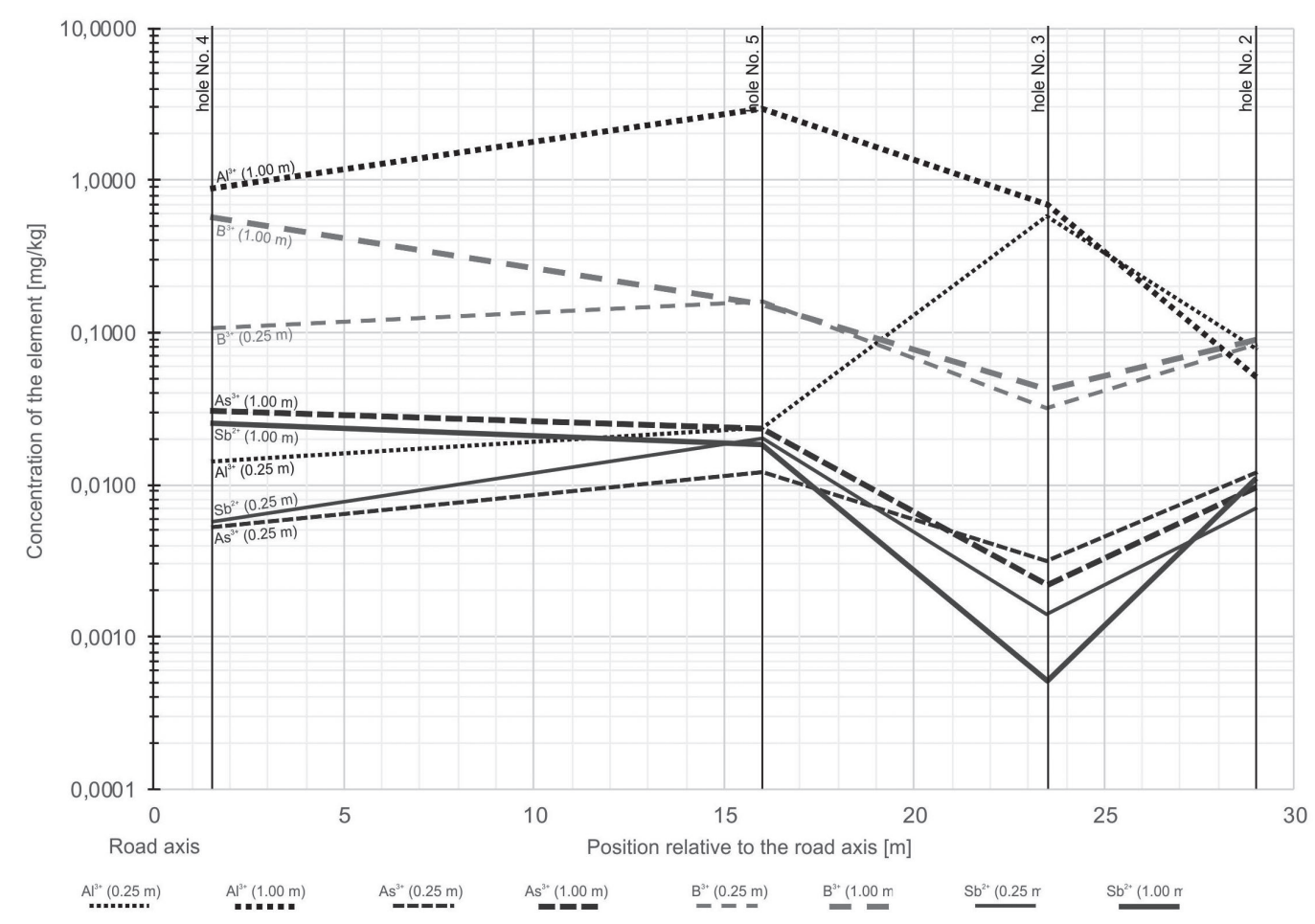

Fig. 4. Concentrations of selected metalloids $[\mathrm{mg} / \mathrm{kg}]$ in ground samples from boreholes 1-7.

$w=28 \%$ at atmospheric precipitation in 2018 at $P=678 \mathrm{~mm}$, after one year chlorides should infiltrate to a depth of about half a meter $(0.48 \mathrm{~m})$. The adopted high values seem to be right owing to the presence of significant sizes of bricks and debris in the investigated soil (parameters adopted based on the author's experience). Because chlorides do not undergo dispersion, disintegration or sorption, they infiltrate deep into the ground while supplying shallow Quaternary groundwater. 


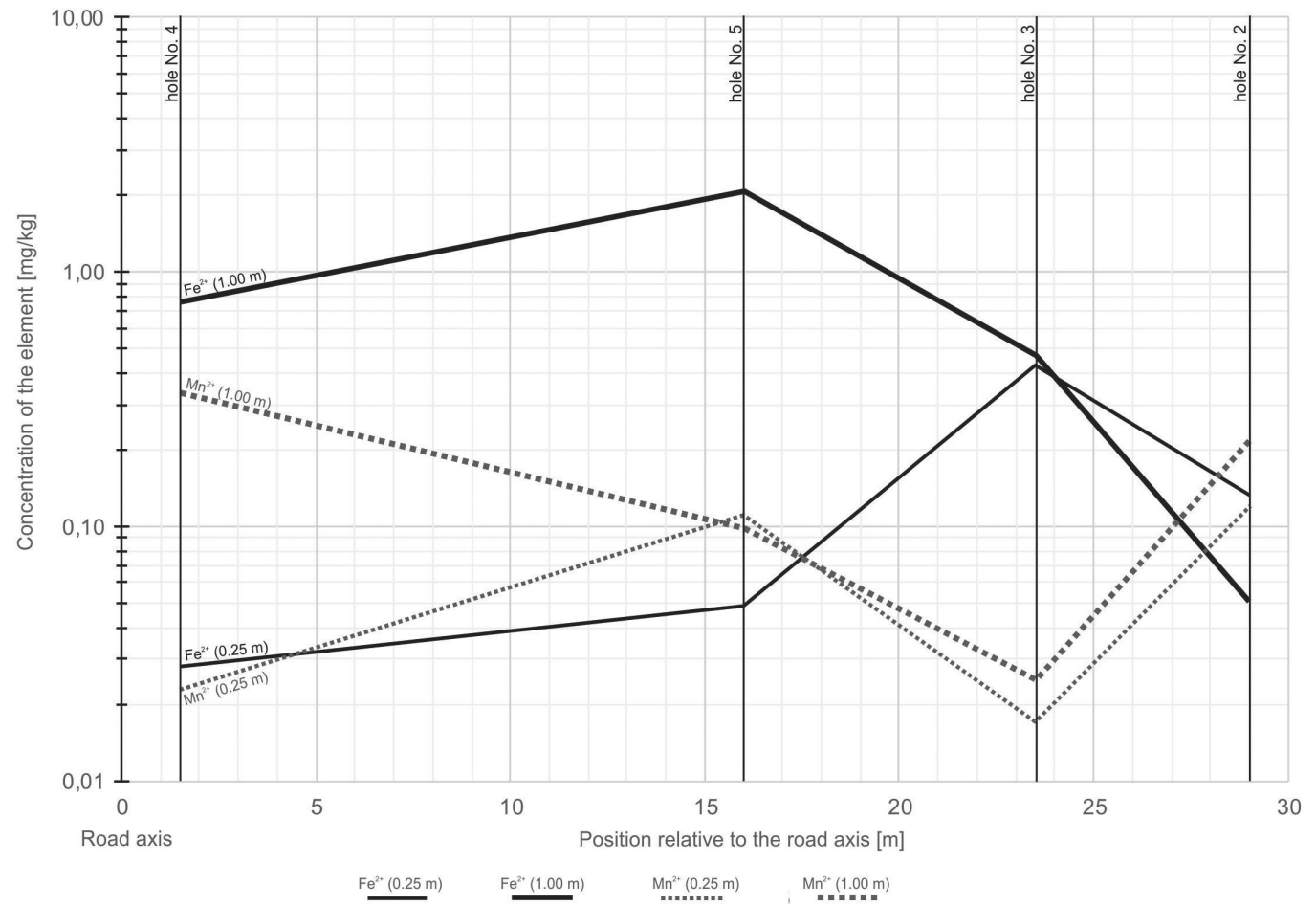

Fig. 5. Concentrations of iron and manganese $[\mathrm{mg} / \mathrm{kg}]$ in ground samples from boreholes 1-7.

Table 2. Concentrations of chlorides $[\mathrm{mg} / \mathrm{kg}]$ in ground samples from boreholes 1-7.

\begin{tabular}{|c|c|c|c|c|c|c|c|c|}
\hline \multirow{2}{*}{$\begin{array}{c}\text { Depth } \\
{[\mathrm{m} \mathrm{bgl}]^{*}}\end{array}$} & \multicolumn{7}{|c|}{ Number of geoengineering boreholes } & \multirow{2}{*}{$\begin{array}{c}\text { Geometric } \\
\text { mean }\end{array}$} \\
\hline & 1 & 2 & 3 & 4 & 5 & 6 & 7 & \\
\hline \multicolumn{9}{|c|}{ October $1 / 10 / 2018$} \\
\hline 0 & 40 & 30 & 42 & 208 & 40 & 32 & 28 & 46 \\
\hline 0.25 & 30 & 26 & 22 & 186 & 110 & 40 & 22 & 44 \\
\hline 0.50 & 16 & 28 & 18 & 232 & 82 & 26 & 18 & 36 \\
\hline 0.75 & 28 & 18 & 22 & 80 & 60 & 20 & 14 & 28 \\
\hline 1.00 & 22 & 14 & 24 & 40 & 48 & 16 & 14 & 22 \\
\hline \multicolumn{9}{|c|}{ December $11 / 12 / 2018$} \\
\hline 0 & 32 & 36 & 50 & 472 & 378 & 146 & 46 & 96 \\
\hline 0.25 & 22 & 16 & 40 & 100 & 18 & 18 & 22 & 26 \\
\hline 0.50 & 12 & 22 & 30 & 174 & 68 & 26 & 20 & 34 \\
\hline 0.75 & 28 & 20 & 20 & 206 & 56 & 22 & 18 & 34 \\
\hline 1.00 & 20 & 14 & 22 & 30 & 30 & 18 & 14 & 20 \\
\hline \multicolumn{9}{|c|}{ January 17/01/2019 } \\
\hline 0 & 30 & 20 & 36 & 266 & 236 & 214 & 30 & 70 \\
\hline 0.25 & 22 & 22 & 30 & 272 & 138 & 30 & 30 & 48 \\
\hline 0.50 & 12 & 18 & 26 & 138 & 50 & 20 & 18 & 28 \\
\hline 0.75 & 26 & 18 & 20 & 230 & 60 & 20 & 14 & 32 \\
\hline 1.00 & 22 & 12 & 24 & 30 & 38 & 16 & 14 & 20 \\
\hline $\begin{array}{c}\text { Geometric } \\
\text { mean }\end{array}$ & 26 & 22 & 24 & 124 & 64 & 26 & 18 & 26 \\
\hline
\end{tabular}

${ }^{*}$ m bgl-metres below ground level 


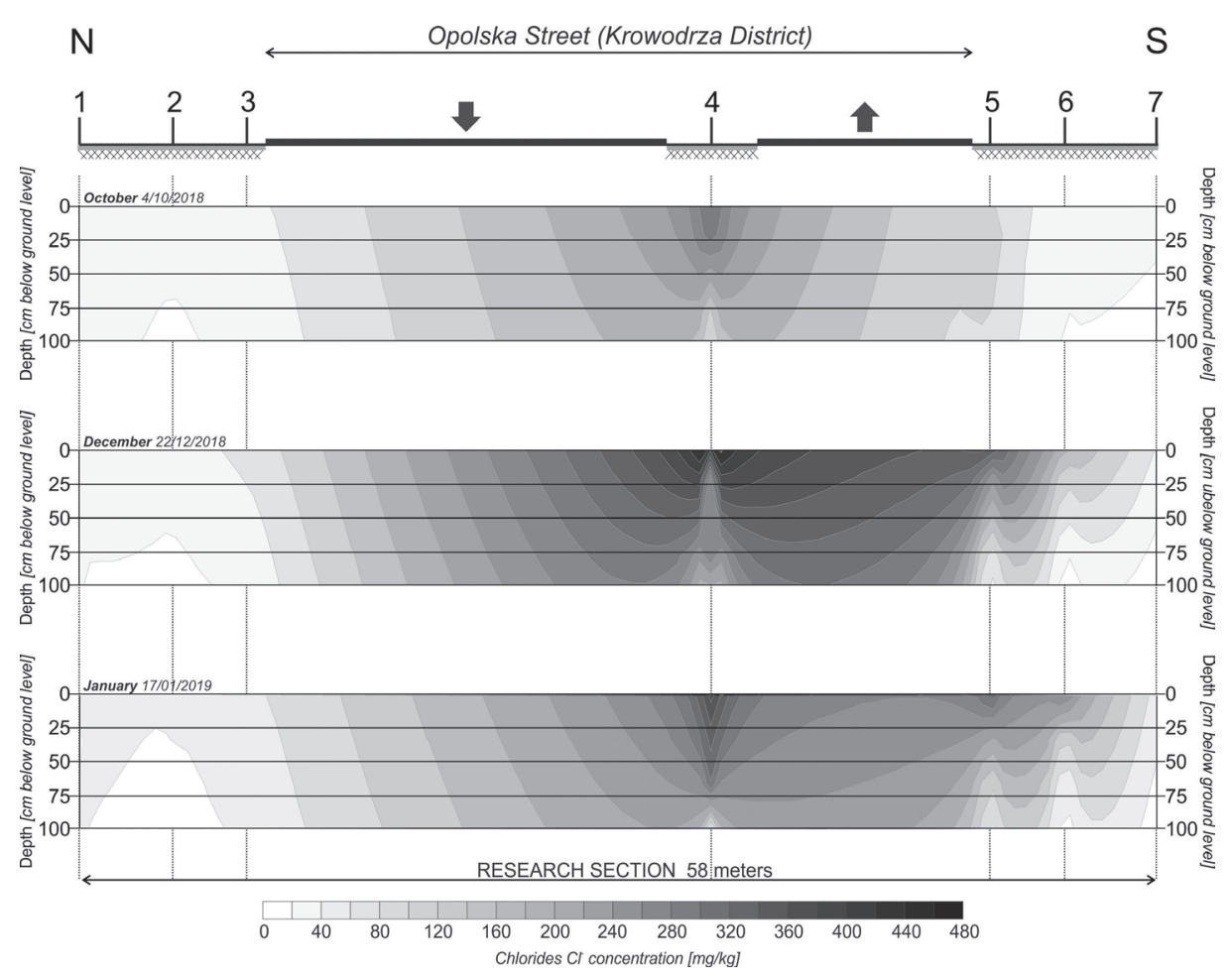

Fig. 6. Distribution of chlorides $[\mathrm{mg} / \mathrm{kg}]$ in the ground below Opolska Street in Krakow.

In total, on the research section in the area of Opolska Street, there was an increase in chlorides in the soil environment by over $1 / 2$ kilogram, i.e., $+561 \mathrm{mg} / \mathrm{kg}$ ( +592 for December and $+530 \mathrm{mg} / \mathrm{kg}$ for January).

High concentrations of chlorides in borehole No. 4 in the green belt in the axis of the road indicate the effect of salting public roads in winter. The maximum difference in the sum of concentrations in the vertical measurement up to 1 meter of depth, in relation to the initial state in October 2018, is the chloride load of $+236 \mathrm{mg} / \mathrm{kg}$ for December. Then in January, the value decreases to $+190 \mathrm{mg} / \mathrm{kg}$, which is on average $+213 \mathrm{mg} / \mathrm{kg}$. This asymmetrical distribution of pollution around the road, with a clear shift of pollution to the south side, probably results from a slight sloping of the terrain, which allows for increasing the surface runoff. None of this is a matter of the location of the pavement and the salting of communication routes in winter, mainly because they are spread evenly in relation to the roadways both on the northern and southern sides. No increase in chloride concentrations was observed in borehole No. 3 .

However, it should be noted that land cover in the side areas along the street in Krakow is diverse and infiltration of polluted waters and/or surface runoff does not occur along the entire length of the road. On the other hand, the position of the green belt is stable. The total length of Opolska Street is $3,400 \mathrm{~m}$, and the green belt separating the road is about $2,900 \mathrm{~m}$, with an average width of $4 \mathrm{~m}$ along the entire length of the street. Analysing the quality of the soil to a depth of $1 \mathrm{~m}$, with an increase in chloride concentrations from winter measurements by an average of $213 \mathrm{mg} / \mathrm{kg}$, the total discharge of chlorides into the ground in winter 2018-2019 only in the green belt amounted to almost $2500 \mathrm{~kg}$ (average $2471 \mathrm{~kg}$ ), i.e., $2^{1 / 2}$ tons of chlorides. This value translates into more than 4 tons of pure $\mathrm{NaCl}$ salt (4073 kg).

\section{Conclusions}

Detailed studies of the chemical composition of the ground along the high-traffic street in Krakow revealed a lack of contamination from metals and metalloids, which occur in the ground at an average level of just a few $\mu \mathrm{g} / \mathrm{kg}$. There is an ongoing improvement in the technical condition of cars and, as a result, fuel combustion processes. Cases of using uncertified fuels are also rare.

Although the tested ground is clean, it turned out that it is not the direct use of public roads (car traffic) that is causing the degradation of the soil and water environment. The most dangerous process that takes place in the studied area is the penetration of road salt in the winter period to the rock mass [27]. Although legislation in Poland requires that the chemical remains on the roadway and/or pavement (communication route) while salting roads in order to maintain their quality, it is difficult to enforce. Salt from public roads gets to the ground surface through exhaust and surface runoff, as well as on car wheels.

The results clearly show that during one winter season (2018-2019), and only through the green belt, 
about $2 \frac{1}{2}$ tons of chlorides leaked into the ground, which translates into 4 tons of road salt $(\mathrm{NaCl}$ rock salt). Salting roads is currently one of the biggest pollution problems for the shallow Quaternary waters in cities.

This means that within the implementation of environmental protection, instead of strictly limiting the use of water, it is necessary to take up active protection. Environmental monitoring is, therefore, crucial in this respect $[28,29]$. Subsequent actions are associated with clean-up of the soil and water environment.

Finding an effective alternative to road salt with a similar economic rate will allow the elimination of a very large load of salt entering the ground and groundwater every year.

It should be noted, however, that the winter of 2018-2019 was exceptionally snowless, i.e., an intensive long-lasting snowfall longer than 1 week with road salting accompanying it occurred only twice: in December 2018 and January 2019. This means that the detection of tons of salt getting into the ground every year could be undervalued. To confirm the study results, work will be carried out in subsequent winter seasons.

\section{Acknowledgements}

This work was supported by the Department of Hydrogeology and Engineering Geology, AGH-UST in Krakow, Poland.

\section{Conflict of Interest}

The author declares no conflict of interest.

\section{References}

1. KLECZKOWSKI A.S., CZOP M., MOTYKA J., RAJCHEL L.Z. Influence of the geogenic and anthropogenic factors on the groundwater chemistry in Krakow (south Poland). Geologia, 35 (1), 117, 2009.

2. GENERAL DIRECTORATE FOR NATIONAL ROADS AND HIGHWAYS (GDDKiA) Organization of winter maintenance of roads in the Małopolska voivodeship in the 2015/2016 season. Krakow, Poland, 2015.

3. GENERAL DIRECTORATE FOR NATIONAL ROADS AND HIGHWAYS (GDDKiA) Synthesis of General Traffic Measurement results. Available online: https:// www.gddkia.gov.pl/pl/2551/GPR-2015 (accessed on 1-072019).

4. GENERAL DIRECTORATE FOR NATIONAL ROADS AND HIGHWAYS (GDDKiA) GDDKiA service. Winter road maintenance. Available online: https://www.gddkia. gov.pl/pl/3013/Zimowe-utrzymanie-drog (accessed on 1-07-2019).

5. KARCZMARZ G. Let's learn to love road salt. Colder countries do not have to, we are doomed to it. Available online: https://spidersweb.pl/autoblog/sol-na-drogachodsniezanie/ (accessed on 1-07-2019), 2018.
6. REGULATION OF THE MINISTER OF THE ENVIRONMENT of October 27, 2005 on the types and conditions of use of funds that can be used on public roads and streets and squares (Journal of Laws No. 230, item 1960), 2005.

7. CZARNA M., KOŁODZIEJCZYK U. On chemical methods of eliminating slushiness. University of Zielona Góra, Scientific Papers 146, Environmental engineering 26, 32, 2012

8. CZARNA M. Review of chemicals used in winter road maintenance in Poland. University of Zielona Góra, Scientific Papers 151, Environmental engineering 31, 18, 2013.

9. MAZUR N. The influence of salt for de-icing roads on the natural environment. Jan Kochanowski University in Kielce 18 (4), 449, 2015.

10. MAZUR Z., RADZIEMSKA M., DEPTUŁA D. The impact of measures to combat slipperiness of the road on chloride content in soils along streets of Olsztyn city. Environment Protection and Natural Resources 50, 212, 2011.

11. HOFMAN J., TRÁVNÍČKOVÁ E., ANDĚL P. Road salts effects on soil chemical and microbial properties at grassland and forest site in protected natural areas. Plant Soil Environ. 58 (6), 282, 2012.

12. ASENSIO E., FERREIRA V.J., GIL G., GARCÍAARMINGOL T., LÓPEZ-SABIRÓN A.M., FERREIRA G. Accumulation of De-Icing Salt and Leaching in Spanish Soils Surrounding Roadways. Int. J. Environ. Res. Public Health. 14, 1498, 2017.

13. MALICKI S. Winter will not surprise drivers. Available online: https://www.portel.pl/wiadomosci/zima-niezaskoczy-drogowcow/94066 (accessed on 1-07-2019), 2016.

14. Krakow CITY HALL, CITY DEVELOPMENT DEPARTMENT. Report on the State of the City 2007. IV. Transport and communication. Publisher: System-Graf. Krakow, 2008.

15. OPOCZYŃSKI K. Summary of the results of the General Traffic Measurement 2015on an off-road voivodship network. General Directorate For National Roads and Highways (GDDKiA) Warszawa, 2016.

16. KLECZKOWSKI A.S., MYSZKA J., SOLECKI T., STOPA J. Krakow's artesian springs of drinking water from Jurassic limestones. Faculty of Geology, Geophysics and Environmental Protection AGH-UST, Krakow 1 (61), 1994.

17. KANOWNIK W., RAJDA W. Sources of surface water pollution in the Sudoł Dominikański stream catchment. Acta Scientiarum Polonorum. Formatio Circumiectus 7 (2), 3, 2008.

18. SKIBA S., DREWNIK M., SZYMAŃSKI W., ŻYŁA M. Soil map of Krakow in 1:20 000 scale. Jagiellonian University in Krakow, Department of Pedology and Soil Geography, 2008.

19. ALEKSANDER-KWATERCZAK U., ZDECHLIK R. Hydrogeochemical characteristics of interstitial water and overlying water in the lacustrine environment. Environ Earth Sci. 75 1352, 2016.

20. KABAŁA C., MUSZTYFAGA E., GAŁKA B., ŁABUŃSKA D., MAŃCZYŃSKA P. Conversion of Soil $\mathrm{pH}$ 1:2.5 $\mathrm{KCl}$ and $1: 2.5 \mathrm{H}_{2} \mathrm{O}$ to $1: 5 \mathrm{H}_{2} \mathrm{O}$ : Conclusions for Soil Management, Environmental Monitoring, and International Soil Databases. Pol. J. Environ. Stud. 25 (2), 647, 2016. 
21. REGULATION OF THE MINISTER OF THE ENVIRONMENT of September 1, 2016 on the manner of conducting the assessment of the pollution of the earth's surface (Journal of Laws of 2016, item 1395), 2016.

22. HOWARD K.W.F., HAYNES J. Groundwater Contamination Due to Road De-icing Chemicals - Salt Balance Implications. Urban Geology 3. Geoscience Canada 20 (1), 1993.

23. FINDLAY A.E.G., KELLY V.R. Emerging indirect and long-term road salt effects on ecosystems. Ann $N Y$ Acad Sci. 1223 (1), 58, 2011.

24. INSTITUTE OF METEOROLOGY AND WATER MANAGEMENT (IMGW) Development of a map of the beginning of the winter season in Poland. National Research Institute. Agreement No. IMGW-PIB NX/K/7398/NX/2015 from 21.01.2015, Warszawa, 2015.

25. MACIOSZCZYK T. Vertical water percolation time as an indicator of the screening aquifers. Przegląd Geologiczny, 47 (8), 1999.
26. WITCZAK S., ŻUREK A. The use of soil and agricultural maps in the assessment of the protective role of soils for groundwater. In Methodology of groundwater protection, AGH Krakow, 155 180, 1994.

27. COOPER C.A., MAYER P.M., FAULKNER B.R. Effects of road salts on groundwater and surface water dynamics of sodium and chloride in an urban restored stream. Biogeochemistry. 121 (1), 149, 2014.

28. PIETRUCIN D. Monitoring of the aquatic environment of an industrial area with multiple sources of pollution. Bulletin of Geography. Physical Geography Series 6, 43, 2013.

29. PIETRUCIN D., CZOP M. Modelling of chemical migration under the overlapping impact of multiple and diverse pollution sources in the area of the "Zachem" Chemical Plant (Bydgoszcz, northern Poland). Bulletin of Geography. Physical Geography Series. 9, 31, 2015.

30. Topographic map. Visualization BDOT10k. Available online: http://mapy.geoportal.gov.pl/imap/?gpmap=gp0 (accessed on 20-03-2019) 